\title{
Neurocysticercosis and HIV Infection: what can we learn from the published literature?
}

\author{
Neurocisticercosis e infección por VIH: ¿Qué se puede aprender de la literatura reportada? \\ Omar HERRERA VAZQUEZ ${ }^{1,2}$, Matthew L. ROMO³, Agnès FLEURY',2
}

\begin{abstract}
Infections caused by the human immunodeficiency virus (HIV) and by the larvae of Taenia solium (i.e., cysticercosis) are still widespread in many developing countries. Both pathologies modify host immune status and it is possible that HIV infection may modulate the frequency and pathogeny of cysticercosis of the central nervous system (i.e., neurocysticercosis [NCC]). Objective: To describe published cases of NCC among HIV-positive patients and to evaluate whether the characteristics of NCC, including frequency, symptoms, radiological appearance, and response to treatment differed between HIV-positive and HIV-negative patients. Methods: Forty cases of NCC/HIV co-infected patients were identified in the literature. Clinical and radiological characteristics, as well as response to treatment, were compared with non-matching historical series of NCC patients without HIV infection. Results: Most of these patients had seizures and multiple vesicular parasites located in parenchyma. Clinical and radiological characteristics were similar between HIV-positive and HIV-negative patients with NCC, as well as between immunocompromised and non-immunocompromised HIV-positive patients. Conclusion: Our review did not reveal clear interactions between HIV and NCC. This may be partially due to the small number of cases and reliance on published research. A systematic, multi-institutional effort aiming to report all the cases of this dual pathology is needed to confirm this finding and to clarify the possible relationship between both pathogens.
\end{abstract}

Keywords: HIV; coinfection; Taenia solium; neurocysticercosis

\section{RESUMO}

Las infecciones causadas por el virus de inmunodeficiencia humana (VIH) y la larva de la Tenia solium siguen estando diseminadas en países en vías de desarrollo. Ambas patologías modifican el estado inmune y es posible que la infección por el VIH module la frecuencia y la patología de la neurocisticercosis (NCC). Objetivo: Describir los casos publicados de NCC en los pacientes VIH positivos y evaluar si las características de la NCC, incluyendo frecuencia, síntomas, presentación radiológica, respuesta a tratamiento, difieren entre los sujetos VIH positivos y VIH negativos. Métodos: Cuarenta casos con coinfección NCC/VIH fueron identificados en la literatura. Se compararon sus características clínico-radiológicas, así como su respuesta al tratamiento con diferentes series de casos históricos no pareados. Resultados: La mayoría de los pacientes NCC/VIH tenían epilepsia y múltiples parásitos vesiculares en el parénquima. Las características clínico-radiológicas de la NCC así como la evolución de los pacientes fueron similares entre pacientes VIH positivos y negativos, así como entre pacientes VIH inmunocomprometidos y no inmunocomprometidos. Conclusión: No encontramos interacciones claras entre VIH y NCC. Este resultado puede haber sido influenciado por el pequeño número de casos y la parcialidad de la información publicada. Un esfuerzo multiinstitucional, sistemático encaminado a reportar todos los casos de esta patología dual es necesario para confirmar estos resultados y esclarecer la relación entre patógenos.

Palabras-clave: HIV; coinfección; Taenia solium; neurocisticercosis.

Human immunodeficiency virus (HIV) continues to be a major public health issue. In 2016, roughly 36.7 million people were infected with HIV, mostly in Africa (Middle East and North Africa: 230,000, Western and Central Africa: 6.5 million, Eastern and Southern Africa: 19 million); Asia and the Pacific region accounted for 5.1 million cases, and Latin America and the Caribbean had about 2 million cases ${ }^{1}$. HIV infection causes different immunological changes, particularly defects in cellular immunity and CD4+ T-lymphocyte function. Immunosuppression increases the odds of infection

IInstituto de Investigaciones Biomédicas, Unidad de Neuroinflamación, UNAM, Ciudad de México, México;

2Instituto Nacional de Neurología y Neurocirugía, Clínica de Neurocisticercosis. Ciudad de México, México.

${ }^{3}$ School of Public Health, Li Ka Shing Faculty of Medicine, The University of Hong Kong. Hong Kong.

Omar Herrera Vazquez iD https://orcid.org/0000-0003-4200-9241; Matthew L. Romo iD https://orcid.org/0000-0002-3038-0644;Agnès Fleury https://orcid.org/0000-0002-8930-2202

Correspondence: Agnès Fleury; Insurgentes sur 3877, Colonia La Fama, Delegación Tlalpan, CP 14269, Ciudad de México, México; E-mail: afleury@ biomedicas.unam.mx

Conflict of interest: There is no conflict of interest to declare.

Received 21 December 2018; Received in final form 06 February 2019; Accepted 11 February 2019. 
by different pathogens and also enables easier transmission from one compartment of the body to another. The most frequent opportunistic infections of the central nervous system (CNS) are toxoplasmosis, cryptococcosis, and tuberculosis ${ }^{2,3}$.

Neurocysticercosis (NCC) is an endemic infection in many countries in Latin America, Africa, and Asia and results from the localization of the larvae of Taenia solium in the $\mathrm{CNS}^{3}$. In the year 2010 it was estimated that there were 372,000 incident cases of cysticercosis, that NCC was the cause of the death of about 28,000 people, and that the disease burden estimated to be caused by cysticercosis was 2.79 million (95\%UI 2.14-3.61 million) DALYs ${ }^{4}$. The presence of $T$. solium in humans induces an immunological response, and it has been shown that the different stages of the parasite (vesicular, colloidal, and calcified) are each associated with a particular immunological profile. In particular, calcified parenchymal NCC is associated with a Th2 response that involves an increase of IL-4, IL-5, and IL-13 in peripheral blood, while severe NCC is associated with an increase of IL-5, IL-6 and IL-10 in CSF, along with a decrease in the lymphoproliferation response . $^{5}$

NCC and HIV are infections that might have some type of interaction. Both diseases are prevalent in many of the same countries, and a recent report from Brazil found that HIV/AIDS was recorded as the most frequent underlying cause of death when NCC was listed as an associated cause of death $^{6}$. Also, although the lifecycle of $T$. solium occurs mainly in rural areas, different case series show that most patients lived in urban settings ${ }^{7}$, similar to patients with HIV $^{8}$. At an immunological level, although both diseases alter the immunological system in different ways, we cannot rule out the possibility that the HIV-associated immunosuppression can modulate the T. solium infection. In this sense, it is interesting to note that infection with the related parasite Taenia crassiceps seems to be more frequent in HIV-positive individuals than in HIV-negative ones?

Considering these antecedents, we described all of the NCC-HIV-positive cases we could identify in the published medical literature. Also, using control studies describing NCC-HIV-negative cases, we assessed whether interactions between the two pathogens could exist, influencing NCC prevalence, symptoms, imaging characteristics, and treatment response, using the medical literature. We specifically hypothesized that immunosuppressed individuals with HIV might have increased NCC prevalence (possibly related to opportunism of NCC) and radiological severity, as well as a decrease of NCC symptoms and response to treatment.

\section{METHODS}

We conducted a scoping review of the literature by mapping the medical literature on HIV and NCC, as our research questions were broad and complex, and could not be condensed into targeted questions that could be answered by a systematic review.

We searched for relevant publications (i.e., original research and case reports) in the following medical databases: MEDLINE \& MEDLINE In-Process (PubMed.gov), Web of Science, Ovid, LILACS, African Index Medicus, EBSCO, and the grey literature (consisting of Google searches), limiting our search to publications written in English, Spanish, French, and Portuguese between 1984 and 2016. The following terms were included: 1. PubMed.gov "neurocysticercosis and HIV/diagnosis" [MeSH] OR "neurocysticercosis and HIV/therapy" [MeSH] OR "neurocysticercosis and HIV/complications" [MeSH], "neurocysticercosis and AIDS/diagnosis" [MeSH] OR "neurocysticercosis and AIDS/therapy" [MeSH] OR "neurocysticercosis and AIDS/complications" [MeSH]. 2. For the remaining medical databases, the search terms "neurocysticercosis and HIV or neurocysticercosis and AIDS" were used, using translated keywords for Spanish, French, and Portuguese. The case definition of NCC was based on the Carpio et al. criteria ${ }^{10}$, and the case definition for HIV infection was based on the Centers for Disease Control and Prevention guidelines $(2014)^{11}$. Reports not meeting these case definitions (e.g., NCC ascertained using serological tests only) or reports completely lacking information on the characteristics of NCC infection (number, stage, and localization of parasites, and clinical features) and on CD4 status were excluded.

The results of our search are depicted in Figure. Detailed information (symptoms, number, location and stage of parasites, CD4 count and outcome) regarding each NCC/HIV case is provided in supplementary Table 1.

Information regarding control groups (i.e., HIVnegative individuals with NCC) is detailed in Table 1. A comparison was made using matched population ${ }^{12}$. The remaining control studies were included based on the following criteria: 1) Similar institutions where NCC/HIVpositive patients were evaluated $^{13}$; 2) pooled estimates of neurological symptoms associated with NCC obtained by a systematic review of the literature ${ }^{14}$; and 3) series of patients from hospital settings in which radiological findings and outcomes were described ${ }^{13,15,16,17,18,19,20,21,44}$.

\section{RESULTS}

\section{Characteristics of NCC in HIV-positive patients}

We identified 40 published cases of patients co-infected with NCC and HIV that met the inclusion criteria (SupplementaryTab le) $22,23,24,25,26,27,28,29,30,31,32,33,34,35,36,37,38,39,40,41,42,43$. The information used to characterize HIV and NCC diseases was heterogeneous between articles and frequently incomplete. Diagnosis was made based on CT scan in 22 cases $(55.0 \%)$ and on MRI in 18 cases $(45.0 \%)$. None of the publications mentioned which infection (NCC or HIV) was acquired first. 

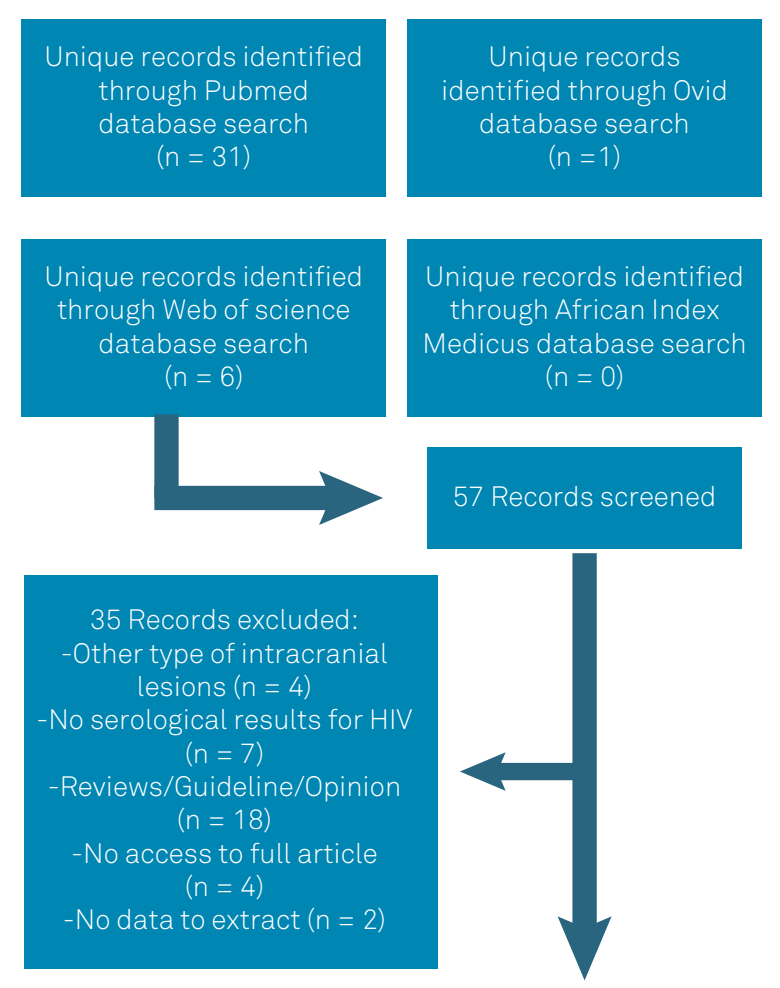

22 papers describing 40 patients with

NCC/HIV co-infection

Figure. Flow chart showing the results of the literature search.

Table 1. Information for control studies used for comparisons with patients co-infected with neurocysticercosis and HIV.

\begin{tabular}{|c|c|c|c|}
\hline $\begin{array}{l}\text { Reference numbers } \\
\text { (control studies, i.e. } \\
\text { NCC/HIV-) }\end{array}$ & Number of included subjects & Information used for the current study & $\begin{array}{l}\text { Reference numbers used for } \\
\text { comparison (NCC/HIV+) }\end{array}$ \\
\hline 12 & $170 \mathrm{HIV}+$ and $170 \mathrm{HIV}-$ & NCC prevalence & 12 \\
\hline 13 & 4098 (neurological patients) & NCC prevalence, Radiological findings & 24 \\
\hline 14 & 2211 (NCC) & Neurological symptoms & $22,24,25,27-43$ \\
\hline 15 & $111(\mathrm{NCC})$ & Radiological findings & $22-43$ \\
\hline 16 & 753 (NCC) & Radiological findings & $22-43$ \\
\hline 18 & 37 (NCC) & Radiological findings & $22-43$ \\
\hline 44 & 206 (NCC) & Radiological findings & $22-43$ \\
\hline 17 & 114 (NCC) & Response to treatment & $22,24-26,29-43$ \\
\hline 19 & 942 (NCC) & Response to treatment & $22,24-26,29-43$ \\
\hline 20 & 38 (NCC) & Response to treatment & $22,24-26,29-43$ \\
\hline 21 & 120 (NCC) & Response to treatment & $22,24-26,29-43$ \\
\hline
\end{tabular}

HIV: Human immunodeficiency virus; NCC: Neurocysticercosis.

Sex was reported for 30 cases $^{22,23,24,25,28,29,30,31,32,33,34,35,36,37,38,39,40,}$ ${ }^{41,42,43} ; 10(33.3 \%)$ were female and $20(66.7 \%)$ male, while individual age (mean $34.8 \pm 11.5$; range 13-72) was reported for 25 cases $^{22,23,24,25,28,29,30,31,32,33,35,36,37,38,39,40,41,43}$.

Regarding symptoms, among the 30 cases with these characteristics clearly described, most of the patients presented with seizures (62.1\%), followed by focal deficit (20.7\%), intracranial hypertension (10.3\%), and headache $(6.9 \%)$ (Table 2
Unique records identified

through LILACS database search $(n=14)$

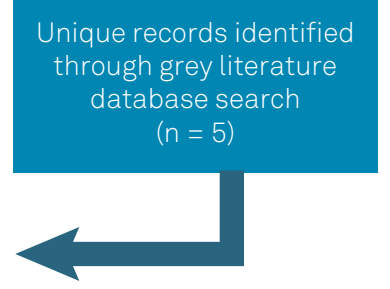


Supplementary Table. Demographic, clinical, and radiological characteristics of the 40 HIV/NCC cases. CD 4 counts and outcome are also reported if available.

\begin{tabular}{|c|c|c|c|c|c|c|}
\hline $\begin{array}{l}\text { ARTICLE (First author, year of } \\
\text { publication, reference number) }\end{array}$ & Age/sex & $\begin{array}{l}\text { Symptoms } \\
\text { related with NCC }\end{array}$ & $\begin{array}{c}\text { Number/location of } \\
\text { parasites }\end{array}$ & $\begin{array}{l}\text { Stage (Vesicular/ } \\
\text { colloidal/calcified) }\end{array}$ & $\begin{array}{c}\mathrm{CD4} \\
\text { (cell/mm3) }\end{array}$ & $\begin{array}{l}\text { Immediate } \\
\text { outcome }\end{array}$ \\
\hline $\begin{array}{l}\text { Thornton, } 1992 \\
\text { \#22 }\end{array}$ & $40 / \mathrm{M}$ & $\mathrm{ICH}$ & $\begin{array}{l}\text { Multiple parenchymal } \\
\text { subarachnoid }\end{array}$ & Vesicular & NA & Improved \\
\hline $\begin{array}{l}\text { Thornton, } 1992 \\
\text { \#22 }\end{array}$ & $30 / \mathrm{M}$ & Focal deficit & Multiple parenchymal & Vesicular & NA & $\begin{array}{l}\text { Not } \\
\text { improved }\end{array}$ \\
\hline $\begin{array}{l}\text { Thornton, } 1992 \\
\text { \#22 }\end{array}$ & $36 / \mathrm{M}$ & Seizure & Multiple parenchymal & Vesicular & NA & $\begin{array}{l}\text { Not } \\
\text { improved }\end{array}$ \\
\hline $\begin{array}{l}\text { Thornton, } 1992 \\
\text { \#22 }\end{array}$ & $25 / M$ & Seizure & Multiple parenchymal & Vesicular & NA & Died \\
\hline $\begin{array}{l}\text { White, } 1995 \\
\text { \#23 } \\
\text { (NCC + cryptococcal meningitis) }\end{array}$ & $29 / \mathrm{M}$ & $\begin{array}{c}\text { Asymptomatic } \\
\text { Incidental finding }\end{array}$ & Multiple parenchymal & Vesicular & 33 & NA \\
\hline $\begin{array}{l}\text { Soto, } 1996 \\
\# 24\end{array}$ & $29 / M$ & $\mathrm{ICH}$ & $\begin{array}{l}\text { Single } \\
\text { Parenchymal }\end{array}$ & Vesicular & 150 & Improved \\
\hline $\begin{array}{l}\text { Soto, } 1996 \\
\# 24 \\
\text { (NCC + Toxo) }\end{array}$ & $41 / F$ & $\begin{array}{c}\text { Asymptomatic } \\
\text { Incidental finding }\end{array}$ & Subarachnoid & $\begin{array}{l}\text { Vesicular, } \\
\text { calcified }\end{array}$ & NA & Improved \\
\hline $\begin{array}{l}\text { Delobel, } 2004 \\
\text { \#25 }\end{array}$ & $45 / \mathrm{M}$ & Focal deficit & $\begin{array}{c}\text { Single subarachnoid } \\
\text { (temporal) /Lumbar } \\
\text { epidural }\end{array}$ & Vesicular & 241 & Improved \\
\hline $\begin{array}{l}\text { Modi, } 2004 \\
\text { Six cases, \#26 }\end{array}$ & NA & NA & $\begin{array}{c}\text { Single (3) } \\
\text { Multiple (3) }\end{array}$ & NA & $106-768$ & Improved \\
\hline $\begin{array}{l}\text { Modi, } 2004 \\
\text { Three cases, \#26 } \\
\text { (2 with NCC+TB, } 1 \text { with } \\
\text { NCC+TB+Toxo) }\end{array}$ & NA & NA & NA & NA & $30-104$ & Improved \\
\hline $\begin{array}{l}\text { Kumwenda, } 2005 \\
\text { \#27 }\end{array}$ & NA & Focal deficit & NA & Calcified & NA & NA \\
\hline $\begin{array}{l}\text { Pandey, } 2005 \\
\# 28\end{array}$ & $24 / \mathrm{M}$ & Seizures & Multiple parenchymal & Calcified & 200 & NA \\
\hline $\begin{array}{l}\text { Chianura, } 2006 \\
\text { \#29 }\end{array}$ & $22 / F$ & Headache & $\begin{array}{l}\text { Multiple parenchymal, } \\
\text { ventricular subarachnoid }\end{array}$ & Colloidal & 473 & Improved \\
\hline $\begin{array}{l}\text { Lillie, } 2006 \\
\# 30\end{array}$ & $26 / F$ & $\mathrm{ICH}$ & Basal subarachnoid & NA & 600 & Improved \\
\hline $\begin{array}{l}\text { Prasad, } 2006 \\
\text { \#31 }\end{array}$ & $51 / F$ & Seizures & Single parenchymal & Colloidal & 350 & Improved \\
\hline $\begin{array}{l}\text { Prasad, } 2006 \\
\# 31\end{array}$ & $40 / \mathrm{M}$ & Seizures & Multiple parenchymal & Colloidal & 32 & Improved \\
\hline $\begin{array}{l}\text { Prasad, } 2006 \\
\text { \#31 }\end{array}$ & $72 / \mathrm{M}$ & Focal deficit & Multiple parenchymal & $\begin{array}{l}\text { Vesicular, } \\
\text { colloidal }\end{array}$ & 105 & Improved \\
\hline $\begin{array}{l}\text { Ramos, } 2007 \\
\text { \#32 }\end{array}$ & $36 / F$ & Headache & Multiple parenchymal & Colloidal & 13 & Died \\
\hline $\begin{array}{l}\text { Serpa, } 2007 \\
\text { \#33 }\end{array}$ & $35 / M$ & Seizure & Single parenchymal & Colloidal & 462 & Improved \\
\hline $\begin{array}{l}\text { Jung } 2008 \\
\# 34\end{array}$ & $N A / F$ & Seizures & Multiple & $\begin{array}{l}\text { Vesicular, } \\
\text { calcified }\end{array}$ & --- & Improved \\
\hline
\end{tabular}

Continue 


\begin{tabular}{|c|c|c|c|c|c|c|}
\hline $\begin{array}{l}\text { Okome-Nkoumou, } 2010 \\
\text { \#35 }\end{array}$ & $27 / F$ & Seizure & Multiple parenchymal & Colloidal & 10 & Improved \\
\hline $\begin{array}{l}\text { Gupta, } 2012 \\
\# 36\end{array}$ & $13 / \mathrm{M}$ & Seizure & Multiple parenchymal & $\begin{array}{l}\text { Vesicular, } \\
\text { colloidal }\end{array}$ & 396 & Improved \\
\hline $\begin{array}{l}\text { Motsepe, } 2012 \\
\# 37\end{array}$ & $46 / F$ & Focal deficit & $\begin{array}{l}\text { Multiple subarachnoid } \\
\text { spinal }\end{array}$ & NA & 46 & Improved \\
\hline $\begin{array}{l}\text { Giordani, } 2013 \\
\# 38\end{array}$ & $24 / \mathrm{M}$ & Seizure & Multiple parenchymal & Colloidal & 24 & Improved \\
\hline $\begin{array}{l}\text { Millogo, } 2013 \\
\text { \#39 }\end{array}$ & $34 / \mathrm{M}$ & Seizures & Multiple parenchymal & Vesicular & NA & Improved \\
\hline $\begin{array}{l}\text { Taha, } 2013 \\
\text { \#40 }\end{array}$ & $34 / F$ & Focal deficit & Multiple parenchymal & $\begin{array}{l}\text { Vesicular } \\
\text { Colloidal }\end{array}$ & 750 & Improved \\
\hline $\begin{array}{l}\text { Anand, } 2015 \\
\# 41\end{array}$ & $40 / \mathrm{M}$ & Seizure & Multiple parenchymal & $\begin{array}{l}\text { Vesicular, } \\
\text { colloidal }\end{array}$ & 350 & Improved \\
\hline $\begin{array}{l}\text { Anand, } 2015 \\
\# 41\end{array}$ & $35 / M$ & Seizure & Multiple parenchymal & $\begin{array}{l}\text { Vesicular, } \\
\text { colloidal, calcified }\end{array}$ & 530 & NA \\
\hline $\begin{array}{l}\text { Anayo, } 2015 \\
4 \text { cases, \#42 }\end{array}$ & $36-45 / M$ & Seizures & Multiple parenchymal & NA & NA & Improved \\
\hline $\begin{array}{l}\text { Martins, } 2015 \\
\# 43\end{array}$ & $36 / F$ & Seizure & Multiple parenchymal & Vesicular & NA & Improved \\
\hline
\end{tabular}

NA: not available; ICH: intracranial hypertension; CSF: cerebrospinal fluid; TB: tuberculosis; Toxo: toxoplasmosis.

Table 2. Neurocysticercosis clinical presentation in symptomatic HIV-negative and -positive patients.

\begin{tabular}{lcc}
\hline Variable & HIV-negative [14] & $\begin{array}{c}\text { HIV-positive } \\
(\mathrm{n}=29)^{*}\end{array}$ \\
\hline Headache & $25.9 \%(10.7-45.0 \% \mathrm{Cl})$ & $2(6.9 \%)$ \\
Seizure & $63.2 \%(51.9-73.8 \% \mathrm{Cl})$ & $18(62.1 \%)$ \\
Focal deficit & $11.8 \%(4.1-22.9 \% \mathrm{Cl})$ & $6(20.7 \%)$ \\
$\begin{array}{l}\text { Intracranial } \\
\text { hypertension }\end{array}$ & $16.3 \%(5.3-31.8 \% \mathrm{Cl})$ & $3(10.3 \%)$ \\
\hline $\begin{array}{l}\text { In cases of symptoms belonging to different categories, only the most severe } \\
\text { symptom was considered for each case. }{ }^{*} \text { Of the } 40 \text { published cases, two } \\
\text { patients did not have symptoms related to NCC (incidental finding) and only } \\
\text { among 29 were symptoms clearly described. }\end{array}$
\end{tabular}

(Table 4). Two patients died; for one of them the cause of death was not NC (thrombocytopenia), and for the other, the cause was not clearly described.

\section{Effect of the intensity of HIV-related immunosuppression on NCC characteristics}

Individual CD4 count was described for only $18 \mathrm{NCC} / \mathrm{HIV}$ cases, 10 patients $(55.6 \%)$ had CD $4 \geq 200$ cells $/ \mathrm{mm}^{3}$ while eight patients (44.4\%) had CD4 $<200$ cells $/ \mathrm{mm}^{323,24,25,28,29,30,}$ $31,32,33,35,36,37,38,40,41$. A comparison of the main characteristics of NCC between the two groups is presented in Table 5. As seen, in the two groups, the main symptom was seizure, most of the parasites were located in the parenchyma and degenerating (colloidal or calcified). Patients improved with treatment in the two groups.
Table 3. Neurocysticercosis radiological presentation (number, location and stage of parasites) in HIV-positive and -negative patients.

\begin{tabular}{|c|c|c|}
\hline Variable & $\begin{array}{c}\text { HIV-negative [13, } \\
15,16,18,44]\end{array}$ & HIV-positive* \\
\hline \multicolumn{3}{|l|}{ Number of cysticerci } \\
\hline Single & $29(25.4 \%)$ & $6(17.1 \%)$ \\
\hline Multiple & $76(63.2 \%)$ & $29(82.9 \%)$ \\
\hline \multicolumn{3}{|l|}{ Location of cysticerci } \\
\hline Parenchymal & $\begin{array}{c}60(54 \%) \\
133(59.6 \%)\end{array}$ & $23(79.3 \%)$ \\
\hline Extraparenchymal & $\begin{array}{c}10-20 \% \\
11(30 \%) \\
51(22.9 \%)\end{array}$ & $4(13.8 \%)$ \\
\hline Mixed & NA & $2(6.9 \%)$ \\
\hline \multicolumn{3}{|l|}{ Stage of cysticerci } \\
\hline Vesicular & $29(25.4 \%)$ & $9(36.0 \%)$ \\
\hline Colloidal & $12(10.5 \%)$ & $7(28.0 \%)$ \\
\hline Calcified & $\begin{array}{c}15(13.2 \%) \\
13(12 \%)\end{array}$ & $2(8.0 \%)$ \\
\hline Mixed & NA & $7(28.0 \%)$ \\
\hline
\end{tabular}

*Information was frequently incomplete. We report only the information when clearly described (in 35 cases for number, 29 for location and 25 for stage).

\section{Effect of HIV on NCC prevalence}

Two comparative studies allowed us to evaluate the effect of HIV on NCC prevalence, since it is possible that NCC represents an opportunistic infection. 
Table 4. Outcome of HIV-positive and -negative patients with neurocysticercosis after cysticidal treatment.

\begin{tabular}{lcc}
\hline Variable & $\begin{array}{c}\text { HIV-negative } \\
{[17,19-21]}\end{array}$ & HIV-positive* \\
\hline Improved & $114(74.5 \%)$ & $32(88.9 \%)$ \\
Not improved & $13(22.8 \%)$ & $2(5.5 \%)$ \\
Died & $2(5.3 \%)$ & $2(5.5 \%)$ \\
\hline *Individual data were reported for 36 patients (Supplementary Table).
\end{tabular}

The first was a study where the prevalence of NCC (with CT-based diagnosis) in 170 matched HIV-positive and HIV-negative patients in northern Tanzania were evaluated and compared ${ }^{12}$. The authors did not find any significant differences in NCC prevalence and clinical manifestations between the two populations.

The second comparison was made using data from two studies that examined the frequency of NCC among HIV-positive and HIV-negative individuals at the Mexican National Institute of Neurology ${ }^{13,24}$. In both studies, NCC diagnosis was made using radiological parameters. The first evaluated the prevalence of NCC among HIV-negative patients admitted to this institution in 1994 and 2004. The authors reported an NCC prevalence of $2.4 \%$ (100/4098) in 1994, and of $2.5 \%(120 / 4706)$ in 2004. The second study described the prevalence of NCC in 91 HIV patients diagnosed between 1987 and 1993. Two of the participants in this study had NCC, with an estimated $2.2 \%$ prevalence of NCC in HIV-positive individuals. Thus, no major difference in NCC prevalence between HIV+ and HIV- populations was found (2.2\% vs. $2.4 \%)$.

\section{Effect of HIV on NCC symptoms, imaging characteristics, and treatment response}

We compiled the symptoms of published NCC/HIV cases $^{22,23,2,4,25,27,28,29,30,31,32,3,33,34,35,36,37,3,38,39,40,41,4,4,43}$, and compared them with a published meta-analysis providing estimates of the manifestations among HIV-negative patients with symptomatic $\mathrm{NCC}^{14}$. The results are presented in Table 2. Within the two groups of patients, seizure was the symptom most frequently reported. The frequency of focal deficit and intracranial hypertension were similar between the two groups of patients and only headache was lower in the HIV-positive group.

Although the published literature was frequently incomplete, we assessed whether HIV seropositivity was associated with differences in number (single vs. multiple), location (parenchymal vs. extraparenchymal), and stage (vesicular, colloidal, calcified, mixed) of parasites. Results in HIV-positive patients $22,23,24,25,26,27,28,29,30,31,32,33,34,35,36,37,38,39,40,41,42,43$ were compared with different series of NCC patients without HIV ${ }^{13,15,16,18,44}$, and are presented in Table 3. Within the two groups of patients, the most frequent radiological presentation was multiple vesicular parasites located in the parenchyma.
Table 5. Characteristics of neurocysticercosis presentation by CD4 count among HIV-positive patients.

\begin{tabular}{|c|c|c|}
\hline Variable & CD4 $\geq 200(n=10)$ & CD4 $<200(n=8)$ \\
\hline \multicolumn{3}{|l|}{ Symptoms* } \\
\hline Headache & $1(10 \%)$ & $1(14.3 \%)$ \\
\hline Seizure & $6(60 \%)$ & $3(42.8 \%)$ \\
\hline Focal deficit & $2(20 \%)$ & $2(28.6 \%)$ \\
\hline $\mathrm{ICH}$ & $1(10 \%)$ & $1(14.3 \%)$ \\
\hline \multicolumn{3}{|l|}{ Parasite location } \\
\hline Parenchyma & $7(70 \%)$ & $7(87.5 \%)$ \\
\hline Extra-parenchyma & $2(20 \%)$ & $1(12.5 \%)$ \\
\hline Mixed & $1(10 \%)$ & 0 \\
\hline \multicolumn{3}{|l|}{ Parasite stage } \\
\hline Vesicular & $1(11.1 \%)$ & $2(28.6 \%)$ \\
\hline Colloidal/calcified & $4(44.4 \%)$ & $4(57.1 \%)$ \\
\hline Mixed & $4(44.4 \%)$ & $1(14.3 \%)$ \\
\hline No data & 1 & 1 \\
\hline \multicolumn{3}{|l|}{ Outcome } \\
\hline Improved & $8(100 \%)$ & $6(85.7 \%)$ \\
\hline Not improved / Died & 0 & $1(14.3 \%)$ \\
\hline No data & 2 & 1 \\
\hline
\end{tabular}

ICH: Intracranial hypertension. * In the group of patients with CD4<200, one patient did not present symptoms related to NCC (incidental finding).

We compiled HIV/NCC cases in which response to treatment was specified $22,24,25,26,29,30,31,32,33,34,35,36,37,38,39,40,41,42,43$. Treatment consisted of surgery and/or cysticidal drugs. It was frequently not described whether the criteria of improvement were clinical or radiological. Period of follow-up was also highly variable and was frequently short after treatment. In cases of no improvement or death, it was difficult to know whether the cause was NCC or an opportunistic infection associated with HIV. The data of NCC/HIV patients were compared with different studies that evaluated the outcomes of the treatment in NCC patients without HIV ${ }^{17,19,20,21}$. As shown in Table 5, most patients of both groups improved with specific treatment (surgery or cysticidal drugs).

\section{DISCUSSION}

HIV infection and NCC are endemic in many of the same geographical regions, which include predominantly developing countries. It is well known that both diseases modulate the immune system and it is possible that some interactions may occur between them. Particularly, immunosuppression could favor the invasion and growth of parasites in CNS, increasing the prevalence and radiological severity of NCC. On the other hand, due to the decrease in inflammatory reaction, symptoms and response to treatment could be diminished. 
To evaluate these hypotheses, we compared different characteristics between HIV-negative and HIV-positive patients, both with NCC. Only 40 individual cases of NCC and HIV coinfection were identified in the literature. The descriptions of the patients in the case reports were frequently not complete and we are conscious that this could generate bias in our results. Publication bias is also especially relevant to consider for the individual cases of HIV and NCC co-infection. Indeed, authors and journals might be more likely to publish case reports that present especially unique or severe disease presentations, making case reports an inaccurate representation of the true nature of the disease presentation. Another limitation that warrants mentioning is that the HIV status of the individuals with NCC in the studies used for controls was not known; however, given the low overall prevalence of HIV in these settings, it seems very unlikely to have influenced the comparisons we made.

In spite of all these limitations, we think that this exercise is interesting to show the current state of the literature and the gaps that future research should fill.

We could not identify any clear differences between HIV-positive and HIV-negative patients regarding the frequency of NCC infection, the clinical-radiological presentations nor the response to treatment.

The frequency of NCC infection was similar in HIV-positive and HIV-negative individuals, consistent with an earlier autopsy study made in Mexico ${ }^{45}$. Furthermore, NCC diagnosis did not appear to be more frequent in HIV individuals with CD4 counts $<200$ cell/ $\mu$ l compared to those with higher counts. It is interesting to note that there were only a few reported cases of NCC among immunosuppressed individuals without $\mathrm{HIV}^{46,47,48,49,50}$, supporting the idea that immunosuppression does not increase susceptibility to NCC. Moreover, we did not find any clear differences in NCC characteristics and outcomes between immunosuppressed and non-immunosuppressed HIV patients (Table 5), data that contradict previous reports suggesting that immunosuppression can increase the frequency of severe radiological presentation of $\mathrm{NCC}^{25,50,51}$. Furthermore, the main symptoms of NCC in HIV-positive and HIV-negative individuals were moderate (seizure, focal deficit), and the frequency of intracranial hypertension (the severest symptom) was similar between both groups (Table 2). It is known that symptoms in NCC mainly depend on the intensity of the inflammatory reaction ${ }^{52}$. Thus, although it was suggested that immunosuppressed patients infected with NCC might present with fewer symptoms compared to HIV-negative immunocompetent patients infected with $\mathrm{NCC}^{45-48}$, and that symptoms might increase when CD4 count is recovered, as occurs in the immune reconstitution inflammatory syndrome (IRIS) and as it was shown in some published cases $^{33,53}$, our data do not enable us to confirm this hypothesis.

Multiple vesicular parenchymal parasites were the most frequent radiological presentation in both groups of patients (HIV-positive and HIV-negative) (Table 3). Some authors reported in preliminary studies an increased frequency of unusual NCC presentations in HIV-positive patients, such as giant cysts, racemose cysticerci or spinal localization (6\% vs. $1 \%$ reported in HIV-negative patients). These unusual NCC presentations might be due to a parasite overgrowth allowed by the reduction in immunological response ${ }^{25,53}$. In our study, the only relevant difference was a higher prevalence of extraparenchymal parasites located at a spinal level. Indeed, in our NCC-HIV-positive sample, 2 of the 6 patients (33.3\%) with extraparenchymal cysts (associated or not with parenchymal cysts) presented with spinal cysts. In one study describing NCC in HIV-negative patients, prevalence of spinal cysts was much lower at $3.36 \%(8 / 238)^{7}$. This difference is striking, and more studies are necessary to confirm this result and to, eventually, explore the factors possibly implied.

Regarding NCC patients' response to treatment, we did not find differences between HIV-positive and HIV-negative patients, nor between immunosuppressed and non-immunosuppressed HIV patients (Tables 4 and 5). This result is intriguing when considered in the context of the possible relevance of inflammation (particularly of Th17 response) in response to NCC treatment ${ }^{54}$. In HIV-positive patients, a decrease of Th17 cells, reflecting the depletion of total CD4+ $\mathrm{T}$ cells occurs ${ }^{55}$, which could modify patients' response to NCC treatment. The apparent contradiction between these data could be attributed to the low number of HIV/NCC subjects included in these studies, as well as to the lack of knowledge regarding the CD4 status of many of the patients.

In conclusion, the description of NCC-HIV-positive cases was quite similar to the results obtained in a previous study gathering 27 cases of NCC-HIV co-infection ${ }^{33}$. As in our study, the authors found that the most frequent presentation was multiple parenchymal lesions, and most of those who were treated responded to cysticidal therapy.

We could not identify any interaction between the two pathologies. However, as said before, it is clear that most of the published cases lack precise information, particularly regarding the intensity of the immunosuppression of the patients, the clinical-radiological and inflammatory status of NCC.

Despite the evident limitations of this study, the information reported herein is original and of interest. Implementing a multi-institutional study that may further increase the available data on individuals afflicted with both NCC and HIV and enabling stronger analysis and conclusions is required. Future research should also seek to answer questions about the clinical management of NCC/HIV co-infection, especially related to known drug-drug interactions between antiretroviral, antiparasitic, and antiepileptic treatments.

\section{Acknowledgments}

The authors thank Alexander Cole Edwards and Roopa Kalsank Pai for proofreading the English version of the manuscript. 
1. Fact sheet-Latest statistics on the status of the AIDS epidemic. Geneva. UNAIDS; [cited 2017 Oct 30]. Available from: http://www.unaids.org/sites/default/files/media_asset/UNAIDS_ FactSheet_en.pdf

2. Kaplan JE, Benson C, Holmes KK, Brooks JT, Pau A, Masur H. Guidelines for prevention and treatment of opportunistic infections in HIV-infected adults and adolescents: recommendations from CDC, the National Institutes of Health, and the HIV Medicine Association of the Infectious Diseases Society of America. MMWR Recomm Rep. 2009 Apr;58 RR-4:1-207.

3. Carpio A, Fleury A, Romo ML, Abraham R. Neurocysticercosis: the good, the bad, and the missing. Expert Rev Neurother. 2018 Apr;18(4):289-301. https://doi.org/10.1080/14737175.2018.1451328

4. Torgerson PR, Devleesschauwer B, Praet N, Speybroeck N, Willingham AL, Kasuga F, et al. World Health Organization estimates of the global and regional disease burden of 11 foodborne parasitic diseases, 2010: A data synthesis. PLoS Med. 2015 Dec;12(12):e1001920. https://doi.org/10.1371/journal.pmed.1001920

5. Fleury A, Cardenas G, Adalid-Peralta L, Fragoso G, Sciutto E. Immunopathology in Taenia solium neurocysticercosis. Parasite Immunol. 2016 Mar;38(3):147-57. https://doi.org/10.1111/pim.12299

6. Martins-Melo FR, Ramos AN Jr, Cavalcanti MG, Alencar $\mathrm{CH}$, Heukelbach J. Neurocysticercosis-related mortality in Brazil, 2000-2011: epidemiology of a neglected neurologic cause of death. Acta Trop. 2016 Jan;153:128-36. https://doi.org/10.1016/j.actatropica.2015.10.011

7. Marcin Sierra M, Arroyo M, Cadena Torres M, Ramírez Cruz N, García Hernández F, Taboada D, et al. Extraparenchymal neurocysticercosis: Demographic, clinicoradiological, and inflammatory features. PLoS Negl Trop Dis. 2017 Jun;11(6):e0005646. https://doi.org/10.1371/journal.pntd.0005646

8. Magadi M, Desta M. A multilevel analysis of the determinants and cross-national variations of HIV seropositivity in sub-Saharan Africa: evidence from the DHS. Health Place. 2011 Sep;17(5):1067-83. https://doi.org/10.1016/j.healthplace.2011.06.004

9. Flammer Anikpeh Y, Grimm F, Lindenblatt N, Zinkernagel A. It isn't always caviar. BMJ Case Rep. 2014 Apr;2014 apr01 1:bcr2013200078. https://doi.org/10.1136/bcr-2013-200078

10. Carpio A, Fleury A, Romo ML, Abraham R, Fandiño J, Durán JC, et al. New diagnostic criteria for neurocysticercosis: reliability and validity. Ann Neurol. 2016 Sep;80(3):434-42. https://doi.org/10.1002/ana.24732

11. Centers for Disease Control and Prevention and Association of Public Health Laboratories. Laboratory testing for the diagnosis of HIV infection: updated recommendations. Atlanta, Georgia, USA ; 2014 [cited 2017 Oct 30]. Available from: https://stacks.cdc.gov/ view/cdc/23447

12. Schmidt V, Kositz C, Herbinger KH, Carabin H, Ngowi B, Naman E, et al. Association between Taenia solium infection and HIV/AIDS in northern Tanzania: a matched cross sectional-study. Infect Dis Poverty. 2016 Dec;5(1):111. https://doi.org/10.1186/s40249-016-0209-7

13. Fleury A, Moreno García J, Valdez Aguerrebere P, de Sayve Durán M, Becerril Rodríguez P, Larralde C, et al. Neurocysticercosis, a persisting health problem in Mexico. PLoS Negl Trop Dis. 2010 Aug;4(8):e805. https://doi.org/10.1371/journal.pntd.0000805

14. Carabin H, Ndimubanzi PC, Budke CM, Nguyen H, Qian Y, Cowan LD, et al. Clinical manifestations associated with neurocysticercosis: a systematic review. PLoS Negl Trop Dis. 2011 May;5(5):e1152. https://doi.org/10.1371/journal.pntd.0001152

15. Serpa JA, Graviss EA, Kass JS, White AC Jr. Neurocysticercosis in Houston, Texas: an update. Medicine (Baltimore). 2011 Jan;90(1):81-6. https://doi.org/10.1097/MD.0b013e318206d13e
16. Sotelo J, Guerrero V, Rubio F. Neurocysticercosis: a new classification based on active and inactive forms: a study of 753 cases. Arch Intern Med. 1985 Mar;145(3):442-5. https://doi.org/10.1001/archinte.1985.00360030074016

17. Sotelo J, del Brutto OH, Penagos P, Escobedo F, Torres B, Rodriguez-Carbajal J, et al. Comparison of therapeutic regimen of anticysticercal drugs for parenchymal brain cysticercosis. J Neurol. 1990 Apr;237(2):69-72. https://doi.org/10.1007/BF00314663

18. Figueroa JJ, Davis LE, Magalhaes A. Extraparenchymal neurocysticercosis in Albuquerque, New Mexico. J Neuroimaging. 2011 Jan;21(1):38-43. https://doi.org/10.1111/j.1552-6569.2009.00452.x

19. Del Brutto OH, Roos KL, Coffey CS, García HH. Meta-analysis: Cysticidal drugs for neurocysticercosis: albendazole and praziquantel. Ann Intern Med. 2006 Jul;145(1):43-51. https://doi.org/10.7326/0003-4819-145-1-200607040-00009

20. Monteiro L, Almeida-Pinto J, Stocker A, Sampaio-Silva M. Active neurocysticercosis, parenchymal and extraparenchymal: a study of 38 patients. J Neurol. 1993 Nov;241(1):15-21. https://doi.org/10.1007/BF00870666

21. Garcia HH, Pretell EJ, Gilman RH, Martinez SM, Moulton LH, Del Brutto $\mathrm{OH}$, et al. A trial of antiparasitic treatment to reduce the rate of seizures due to cerebral cysticercosis. N Engl J Med. 2004 Jan;350(3):249-58. https://doi.org/10.1056/NEJMoa031294

22. Thornton CA, Houston S, Latif AS. Neurocysticercosis and human immunodeficiency virus infection: a possible association. Arch Neurol. 1992 Sep;49(9):963-5. https://doi.org/10.1001/archneur.1992.00530330087021

23. White AC Jr, Dakik H, Diaz P. Asymptomatic neurocysticercosis in a patient with AIDS and cryptococcal meningitis. Am J Med. 1995 Jul;99(1):101-2. https://doi.org/10.1016/S0002-9343(99)80113-2

24. Soto Hernandez JL, Ostrosky Zeichner L, Tavera G, Gomez Avina A. Neurocysticercosis and HIV infection: report of two cases and review. Surg Neurol. 1996 Jan;45(1):57-61. https://doi.org/10.1016/0090-3019(95)00259-6

25. Delobel P, Signate A, El Guedj M, Couppie P, Gueye M, Smadja D, et al. Unusual form of neurocysticercosis associated with HIV infection. Eur J Neurol. 2004 Jan;11(1):55-8. https://doi.org/10.1046/j.1351-5101.2003.00696.x

26. Modi M, Mochan A, Modi G. Management of HIV-associated focal brain lesions in developing countries. QJM. $2004 \mathrm{Jul}$;97(7):413-21. https://doi.org/10.1093/qjmed/hch080

27. Kumwenda JJ, Mateyu G, Kampondeni S, Dam AP, van Lieshout L, Zijlstra EE. Differential diagnosis of stroke in a setting of high HIV prevalence in Blantyre, Malawi. Stroke. 2005 May;36(5):960-4. https://doi.org/10.1161/01.STR.0000162585.97216.ef

28. Pandey K, Sinha PK, Das VR, Sur D, Kumar N, Bhattacharya SK. Neurocysticercosis in a patient with visceral leishmaniasis co-infected with HIV: a case report. Infect Dis Clin Pract. 2005;13(3):144-5. https://doi.org/10.1097/01.idc.0000166957.37141.ff.

29. Chianura L, Sberna M, Moioli C, Villa MR, Orcese C, Causarano R. Neurocysticercosis and human immunodeficiency virus infection: a case report. J Travel Med. 2006 Nov-Dec ;13(6)376-80. https://doi.org/10.1111/j.1708-8305.2006.00074.x

30. Lillie P, Parsonage M, Barlow G, Thaker H. Neurocysticercosis with communicating hydrocephalus in an HIV-positive subject. HIV Med. 2006;7 Suppl. 1:37.

31. Prasad S, MacGregor RR, Tebas P, Rodriguez LB, Bustos JA, White AC Jr. Management of potential neurocysticercosis in patients with HIV infection. Clin Infect Dis. 2006 Feb;42(4):e30-4. https://doi.org/10.1086/499359 
32. Ramos JM, Masia M, Padilla S, Bernal E, Martin-Hidalgo A, Gutiérrez F. Fatal infection due to larval cysts of cestodes (neurocysticercosis and hydatid disease) in human immunodeficiency virus (HIV) infected patients in Spain: report of two cases. Scand J Infect Dis. 2007;39(8):719-23. https://doi.org/10.1080/00365540701242392

33. Serpa JA, Moran A, Goodman JC, Giordano TP, White AC Jr. Neurocysticercosis in the HIV era: a case report and review of the literature. Am J Trop Med Hyg. 2007 Jul;77(1):113-7. https://doi.org/10.4269/ajtmh.2007.77.113

34. Jung A, Thaker H, Ming A. Casualties of conflict: a case report of neurocysticercosis, reactivation of toxoplasmosis in an HIV positive pregnant patient. Eur J Neurol. 2008;15 Suppl. 3:342.

35. Okome-Nkoumou MM, Ondounda M, Dzeing-Ella A, Mounguengui D, Madjinou MI, Clevenbergh P, et al. Epileptiform seizures revealing neurocysticercosis: report of two clinical cases in Libreville, Gabon. Trop Doct. 2010 Oct;40(4):235-7. https://doi.org/10.1258/td.2010.090493

36. Gupta V, Yadav TP. "Starry sky"-appearing neurocysticercosis in paediatric HIV infection. J Indian Acad Clin Med. 2012 Oct:13(4):316-8.

37. Motsepe T, Ackerman D. Spinal and vertebral neurocysticercosis in an HIV-positive female patient. SAJEI. 2012;27(3):133-6. https://doi.org/10.1080/10158782.2012.11441499.

38. Giordani MT, Tamarozzi F, Cattaneo F, Brunetti E. Three cases of imported neurocysticercosis in Northern Italy. J Travel Med. 2014 Jan-Feb;21(1):17-23. https://doi.org/10.1111/jtm.12066

39. Millogo A. Epilepsy revealing neurocysticercosis in an HIV positive patient with subcutaneous nodules. North Afr Middle East Epilepsy J. 2013 Jan-Feb;2(1):8-9.

40. Taha H, Das S. Cerebral mass in HIV infection. BMJ. 2013 Oct;347 oct24 2:f6314. https://doi.org/10.1136/bmj.f6314

41. Anand KS, Wadhwa A, Garg J, Mahajan RK HIV-Associated Neurocysticercosis. J Int Assoc Provid AIDS Care. 2015 Mar-Apr;14(2):120-2. https://doi.org/10.1177/2325957414555232

42. Anayo N, Agba L, Poko M, et al. Neurocysticercosis and HIV in 4 cases observed at chu de lome. J Rech Sci Univ Lom (Togo). 2015;17:331-6.

43. Martins JC, Cruzeiro MM, Pires LA. Neurotoxoplasmose e neurocisticercose em paciente com AIDS: relato de caso. Rev Neurocienc. 2015;23(3):443-50. https://doi.org/10.4181/RNC.2015.23.03.1043.08p

44. Sáenz B, Ruíz-Garcia M, Jiménez E, Hernández-Aguilar J, Suastegui R, Larralde C, et al. Neurocysticercosis: clinical, radiologic, and inflammatory differences between children and adults. Pediatr Infect Dis J. 2006 Sep;25(9):801-3. https://doi.org/10.1097/01.inf.0000233548.81204.97

45. Jessurun J, Barrón-Rodríguez LP, Fernández-Tinoco G, Hernández-Avila M. The prevalence of invasive amebiasis is not increase in patients with AIDS: short communication. AIDS. 1992 Mar;6(3):307-10. https://doi.org/10.1097/00002030-199203000-00008

46. Purvey S, Lu K, Mukkamalla SK, Anandi P, Dumitriu B, Kranick S, et al. Conservative management of neurocysticercosis in a patient with hematopoietic stem cell transplantation: a case report and review. Transpl Infect Dis. 2015 Jun;17(3):456-62 https://doi.org/10.1111/tid.12392

47. Gordillo-Paniagua G, Muñoz-Arizpe R, Ponsa-Molina R. Unusual complication in a patient with renal transplantation: cerebral cysticercosis. Nephron. 1987;45(1):65-7. https://doi.org/10.1159/000184074

48. Barra Valencia V, Moreno Elola-Olaso A, Fundora Suárez Y, Meneu Díaz JC, Jiménez de los Galanes SF, Pérez Saborido B, et al. Second case of neurocysticercosis in a patient with liver transplantation (first case in Spain): a case report. Transplant Proc. 2007 Sep;39(7):2454-7. https://doi.org/10.1016/j.transproceed.2007.07.049

49. Hoare M, Gelson WT, Antoun N, Alexander GJ. Early recurrence of neurocysticercosis after orthotopic liver transplant. Liver Transpl. 2006 Mar;12(3):490-1. https://doi.org/10.1002/lt.20643

50. Mauad T, Battlehner CN, Bedrikow CL, Capelozzi VL, Saldiva $\mathrm{PH}$. Case report: massive cardiopulmonary cysticercosis in a leukemic patient. Pathol Res Pract. 1997;193(7):527-9. https://doi.org/10.1016/S0344-0338(97)80108-2

51. Sanz CR. Host response in childhood neurocysticercosis. Some pathological aspects. Childs Nerv Syst. 1987;3(4):206-7. https://doi.org/10.1007/BF00274046

52. Fleury A, Escobar A, Fragoso G, Sciutto E, Larralde C. Clinical heterogeneity of human neurocysticercosis results from complex interactions among parasite, host and environmental factors. Trans R Soc Trop Med Hyg. 2010 Apr;104(4):243-50. https://doi.org/10.1016/j.trstmh.2010.01.005

53. Manzardo C, Guardo AC, Letang E, Plana M, Gatell JM, Miro JM. Opportunistic infections and immune reconstitution inflammatory syndrome in HIV-1-infected adults in the combined antiretroviral therapy era: a comprehensive review. Expert Rev Anti Infect Ther. 2015 Jun;13(6):751-67. https://doi.org/10.1586/14787210.2015.1029917

54. Cárdenas G, Fragoso G, Rosetti M, Uribe-Figueroa L, Rangel-Escareño C, Saenz B, et al. Neurocysticercosis: the effectiveness of the cysticidal treatment could be influenced by the host immunity. Med Microbiol Immunol. 2014 Dec;203(6):373-81. https://doi.org/10.1007/s00430-014-0345-2

55. Dunay GA, Tóth I, Eberhard JM, Degen O, Tolosa E, van Lunzen J, et al. Parallel assessment of Th17 cell frequencies by surface marker co-expression versus ex vivo IL-17 production in HIV-1 infection. Cytometry B Clin Cytom. 2016 Nov;90(6):486-92. https://doi.org/10.1002/cyto.b.21352 